\title{
Patient Safety: When Treatment Goes Right, But Something Goes Tragically Wrong
}

\author{
Joni Aldrich* \\ Department of Orthopedics, USA
}

Submission: April 27, 2017; Published: May 05, 2017

"Correspondence Address: Joni Aldrich, Department of Orthopedics, USA, Tel: 336-403-4112; Email: joni@jonialdrich.com

\section{Hoping for the Best}

Emily Jerry was just like any two-year-old...full of life and enthusiasm. Her blond ringlets and startlingly blue eyes endeared her to everyone she met. Unfortunately, her little body was holding a secret that would blow her families world apart. When she was diagnosed, everyone including the health care team responsible for her care was determined to save Emily.

The Jerry family was prepared for the worst, but hoping for the best. Emily's oncologist said she would be sick following chemo. That never happened; she would go home after her chemo treatment, and go right out to play with her siblings. Sometimes, when the cancer patient is feeling no ill effects from the treatment, it's not working. But little Emily's MRI showed that her grapefruit-sized tumor was completely gone. Her amazed oncologist called it "a miracle".

\section{Surprised by the in Between}

Right before Emily's 2nd birthday, the oncologist talked her parents into one final round of chemotherapy to eliminate the cancer forever. The first days went great. On what was supposed to be Emily's final day of chemo, she suddenly complained of terrible pain and went into a coma. Having some healthcare experience, her father, Chris Jerry, walked back to Emily's treatment room in a shock-filled daze. What happened? He reached down into the trashcan, and what he found seemed like an impossibility. There it was...the smoking gun. Emily's chemotherapy had been mixed with the wrong concentration of saline solution.

Eleven years ago, Chris and his wife had to make the hardest decision any parent can face...taking their baby off life support to go with the angels. At that moment, they didn't care that Emily's legacy would live on to save others from preventable medical errors. They like the medical team responsible for their daughter's care were in deepest shock. How could this happen? When absolutely everything goes right which rarely happens in cancer treatment how could this oncological healthcare team still lose their patient?

\section{Unprepared for the Worst}

The investigation found that an inadequately trained pharmacy technician was on duty the day of Emily's last chemo. Not knowing the potential tragic consequences, she had picked up the wrong concentration of saline solution. A system of checks and balances that should have sent the medical error grinding to a halt sent it straight through the system. Questions went unanswered. This true story has to represent a physician's worst nightmare. Imagine doing everything right throughout the course of caring for a patient with cancer, and senselessly losing them anyway because of a preventable medical error! Every person involved in the tragedy changed for the rest of their lives in the blink of an eye.

Emily was not the only victim. The nurse responsible for Emily's care that day who had spent decades lovingly caring for patients resigned from nursing forever. Emily's mother sought revenge against the pharmacist; he lost his license and went to jail regardless of the fact that he did not mix Emily's chemo. From the time of his childhood, he had wanted to be a pharmacist. Emily's tragic death sent unthinkable ripples of disbelief and destruction throughout the fabric of healthcare at that hospital.

\section{An Advocate's View}

Emily's father knew that nobody meant to harm Emily. Chris realized that the processes and protocol the system itself had failed. Who made the decision to put a poorly trained pharmacy technician in charge of mixing the chemotherapy that was pumped directly into Emily's veins? Hospital management responsible for hiring decisions did not mean to kill Emily either!

Note: Chris Jerry is the founder of the Emily Jerry Foundation (www.emilyjerryfoundation.org), a non-profit dedicated to eliminating preventable medical errors (with particular 


\section{Cancer Therapy \& Oncology International Journal}

emphasis on medication errors like the one that killed his daughter).

\section{Part of the Solution: A Comprehensive Solution to Preventable Medical Errors}

The world can no longer deny (or hide) the preventable medical error healthcare crisis. Medication errors, misdiagnosis, wrong surgical sites, healthcare-acquired infections...these are all critical flaws that lead to the most senseless cause of death in healthcare today and countless other patients who do not die live forever-changed lives with significant consequences.

To date, most of the focus has been on front line staff doctors, nurses, pharmacists and so forth that provide direct medical care. We believe that to effect permanent, long-term progress in preventing medical errors, all of the following need to be included in the scope of change:
A. Management
B. Technology
C. Medical Care Team
D. Patient
E. Caregiver

Yes, everyone involved in patient care including the patient and caregiver should be part of the solution.

\section{About the Author}

For the past decade, Joni Aldrich (www.jonialdrich.com) has advocated for safe patient care in honor of her husband and mother who were both lost to cancer. She has authored 7 books, magazine articles, and produced over 1,500 radio programs, interviewing researchers, physicians, foundations, caregivers and patients from around the world. Joni is the Chairman of the Board for the Emily Jerry Foundation.

Your next submission with Juniper Publishers will reach you the below assets

- Quality Editorial service

- Swift Peer Review

- Reprints availability

- E-prints Service

- Manuscript Podcast for convenient understanding

- Global attainment for your research

- Manuscript accessibility in different formats

( Pdf, E-pub, Full Text, Audio)

- Unceasing customer service

Track the below URL for one-step submission https://juniperpublishers.com/online-submission.php 